REVIEW

\title{
Sudden unexpected death in infancy and socioeconomic status: a systematic review
}

\author{
N Spencer, S Logan
}

J Epidemiol Community Health 2004;58:366-373. doi: 10.1136/jech.2003.011551

This paper aimed to systematically review observational studies documenting the relation between sudden unexpected death in infancy and socioeconomic status. A search of two electronic databases (Medline 1966 to November 2002; Embase 1981 to November 2002) yielded 52 case-control or cohort studies meeting the inclusion criteria. An increased risk of sudden unexpected death in infancy was reported in 51 studies and 32 of 33 studies reporting graded measures of socioeconomic status showed a dose-response relation of sudden death with socioeconomic status. Of the 10 studies in which adjustment was made for maternal smoking, socioeconomic status retained an independent effect on infant death in nine. The effect of socioeconomic status was also independent of birth weight in 10 of 11 studies and independent of sleeping position in two. The included studies reported a significant association of socioeconomic status with sudden unexpected death in infancy with risk of infant death increasing with greater exposure to adverse social circumstances. The findings support a significant role for adverse social circumstances in the pathways to sudden unexpected death in infancy.

See end of article for authors' affiliations

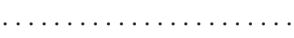

Correspondence to: Professor N Spencer, School of Postgraduate Medical Education, University of Warwick, Warwick, Coventry CV4 7AL, UK; n.j.spencer@ warwick.ac.uk

Accepted for publication 28 October 2003
D espite recent changes in the epidemiology of sudden unexpected death in infancy, ${ }^{1}$ it remains the most significant cause of infant death in developed countries. The term sudden unexpected death in infancy (SUDI) is used in this study in preference to the more commonly used sudden infant death syndrome (SIDS). Firstly, SUDI incorporates all cases of SIDS, defined as the sudden death of an infant under the age of 1 year that remains unexplained after thorough case investigation including performance of a complete necropsy, examination of the death scene, and review of the clinical history, ${ }^{2}$ while allowing for inclusion of unexpected deaths not fully complying with this strict definition but having common associations and risk factors. ${ }^{3}$ Secondly, many of the studies included in this review predated the adoption of a strict definition for SIDS and few would have had systems in place to ensure the thorough case investigation required by the definition. For these reasons, we have adopted a similar approach to that used by the UK Confidential Enquiry into Stillbirths and Deaths in Infancy (CESDI). ${ }^{3}$
A link between low socioeconomic status and SUDI has been noted in much of the literature. ${ }^{4}$ Socioeconomic status represents a constellation of factors reflecting social position and social circumstances including income, occupation, education, and ownership of resources such as housing. For the purposes of this study, we have included marital status and maternal age that are not strictly socioeconomic status variables but have been consistently shown to be strongly associated with measures of social status especially in studies of pregnancy and infant outcome.

The relation of low socioeconomic status and SUDI is important in that aetiological hypotheses need to be consistent with the observed social patterns. It has been suggested that smoking "accounts for" the socioeconomic differences in risk of SUDI. ${ }^{6} 7$ It is well reported that smoking patterns by social class vary between countries and, over time, within countries. ${ }^{8}$ Other independent risk factors for sudden unexpected infant death, such as birth weight and sleeping position, ${ }^{1}$ are also socially patterned. It seems probable that socioeconomic status rather than being a direct, proximal cause of sudden infant death exerts its effect through mediating variables such as smoking, birth weight, and sleeping position. This study provides an opportunity to examine the links between socioeconomic status and SUDI between countries and over time and contribute to a better understanding of the nature of the relation.

\section{METHODS}

A systematic search was undertaken to identify case-control and cohort studies in which the relation between socioeconomic status and SUDI was examined.

\section{Inclusion criteria}

Case-control and cohort studies of SUDI or SIDS that included author defined useable relative risks or odds ratios associated with measures of socioeconomic status and met methodological criteria.

\section{Methodological criteria}

For case-control studies

(a) selection of an appropriate control groupthat is, controls from the same population, selected with minimal bias and of similar age

(b) the same method of ascertainment of exposure data for cases and controls

Abbreviations: SIDS, sudden infant death syndrome; SUDI, sudden unexpected death in infancy 


\section{Key points}

- The association of sudden unexpected death in infancy with social disadvantage was demonstrated in 51 of 52 case-control and cohort studies published since 1965.

- The association was independent of maternal smoking in 9 of 10 studies.

- Social disadvantage is important to an understanding of the epidemiology of sudden unexpected infant death and should not be dismissed as an unmodifiable variable.

(c) analysis took account of matching where appropriate

(d) exposure data were available for $>80 \%$ of both cases and controls

\section{For cohort studies}

(a) no evidence of biased case ascertainment by exposure status-only studies in which cases were ascertained from whole populations and not selected sources such as specialist hospitals were included

\section{Socioeconomic status measures}

Measures of socioeconomic status were included whether measured at the individual or area level. These were: social class (registrar general's social class in UK studies), occupation, income, deprivation (as measured by deprivation indices), housing tenure, overcrowding, maternal education, marital status, and maternal age.

\section{Search strategy}

Two electronic databases (Medline 1966-2002; Embase 19812002) were searched for studies of the outcome of interest (search terms included: SIDS; sudden infant death syndrome; sudden unexpected death in infancy; postneonatal mortality; cot death; crib death) and the exposure of interest (search terms included: social class; occupation; maternal age; maternal education; marital status; socioeconomic status; income; poverty; deprivation usually represented by area based deprivation indices based on census data; overcrowding; social factors; risk factors) with appropriate truncations and mis-spellings. A citation search was undertaken for identified studies in the Science Citation Index. Additional socioeconomic status measures were included in studies identified using the above list of measures. They included: parental education; economy of the home, house repair, housing density, cohabitation, and social disadvantage. A secondary search using these terms yielded 34 abstracts and produced no new studies.

Secondary search of the bibliographies of the papers identified by the electronic search was undertaken. Where gaps in data were identified, authors were asked to provide supplementary data. Titles and abstracts of studies identified by electronic searches were examined for possible relevance and those that might meet the inclusion criteria retrieved. The full papers were read by both reviewers (NJS and SL) independently to determine whether they met the inclusion criteria. Disagreements were resolved by consensus.

\section{Analysis}

Each of the studies identified was classified according to whether an increased risk of SUDI was reported to be associated with each measure of socioeconomic status studied. In addition, studies that reported graded measures of socioeconomic status were examined for the presence of a gradient or trend. To further explore the debate on the relation between socioeconomic status and SUDI, the results of studies that attempted to control for potential confounding of the effect of socioeconomic status on SUDI were included in a separate table (table 3). Smoking in pregnancy, birth weight, and sleeping position are socially patterned and also important risk factors for sudden infant death. Studies that adjusted for these variables were included in table 3.

\section{RESULTS}

The titles and abstracts of 380 studies identified by the search strategy were examined. A total of 110 published papers and abstracts potentially meeting the inclusion criteria were reviewed. Sixty discrete studies, fulfilling the inclusion criteria, were identified with publication dates from 1966 to December 2002 reporting data on infants born between 1956 and 1998. Eight studies were excluded as they failed to meet methodological criteria (table 1).

Fifty two studies were included in the review (table 2). The studies were conducted in 16 countries, 15 in developed countries and one in a developing country (Brazil). Most of the studies were conducted in the USA and the UK. Thirty were case-control studies and 22 cohort studies.

Only 2 of the 52 studies failed to show a statistically significant relation between sudden unexpected death and at least one measure of socioeconomic status. In one of these studies, the results suggested an association with low social class but failed to reach conventional levels of statistical significance. Six of the remaining 50 studies reported a positive relation between low socioeconomic status and sudden unexpected death for all socioeconomic status measures used. No studies reported an increased risk with any measure of higher socioeconomic status. Thirty three studies reported graded measures of socioeconomic status. Thirty two of these showed a significant gradient for at least one socioeconomic status measure and the remaining study showed a trend but failed to reach conventional levels of statistical significance.

\begin{tabular}{|c|c|c|c|}
\hline Author/year of publication & Country & Study type & Reason for exclusion \\
\hline Bergman et al ${ }^{\prime} 72^{\circ}$ & USA & Cohort & $\begin{array}{l}\text { No denominator data } \\
\text { available }\end{array}$ \\
\hline Mason et al ${ }^{\prime} 80^{10}$ & UK & Cohort & No denominator data given \\
\hline Anderson et al ' $93^{\prime \prime}$ & Australia & Cohort & $\begin{array}{l}\text { Data for OR estimation not } \\
\text { available }\end{array}$ \\
\hline $\begin{array}{l}\text { Kohlendorfer et a }{ }^{12} \\
\text { Cooke ' } 98^{13}\end{array}$ & $\begin{array}{l}\text { Austria } \\
\text { UK }\end{array}$ & $\begin{array}{l}\text { Case-control } \\
\text { Case-control }\end{array}$ & $\begin{array}{l}<80 \% \text { of cases followed up } \\
\text { Data for OR estimation not } \\
\text { available }\end{array}$ \\
\hline Arnestad et al $2001^{13 a}$ & Norway & Case-control & $\begin{array}{l}<80 \% \text { of cases/controls } \\
\text { followed up }\end{array}$ \\
\hline
\end{tabular}


Table 2 Studies included in the review

\begin{tabular}{|c|c|c|c|c|c|}
\hline \multirow{2}{*}{$\begin{array}{l}\text { Author/country/year of } \\
\text { publication }\end{array}$} & \multirow[b]{2}{*}{ Study type } & \multirow{2}{*}{$\begin{array}{l}\text { Main SES measure/s } \\
\text { (number of categories) }\end{array}$} & \multirow[b]{2}{*}{ Unadjusted RR/OR $(95 \% \mathrm{Cl})^{*}$} & \multicolumn{2}{|c|}{ Gradient/trend } \\
\hline & & & & Estimated & Present \\
\hline \multirow{2}{*}{$\begin{array}{l}\text { Carpenter and Shaddick, } \\
\text { UK, ' } 65^{14}\end{array}$} & Case-control & Marital status (2) & 2.49 (1.01 to 6.27$)$ & N/A & N/A \\
\hline & & Maternal age (2) & $8.53(1.80$ to 55.5$)$ & N/A & N/A \\
\hline $\begin{array}{l}\text { Steele and Langworth, } \\
\text { Canada, }{ }^{\prime} 66^{15}\end{array}$ & Case-control & Maternal age (5) & 4.75 (1.34 to 18.4$)$ & Yes & Yes \\
\hline $\begin{array}{l}\text { Valdes-Dapena et al, } \\
\text { USA, ' } 68^{16}\end{array}$ & & Socioeconomic level (3)† & 4.59 (3.06 to 6.88 ) & Yes & Yes \\
\hline Strimer et al, USA, ' $69^{17}$ & Cohort & $\begin{array}{l}\text { Median income of census } \\
\text { tracts (9) }\end{array}$ & $5.96(3.81$ to 9.36$)$ & Yes & Yes \\
\hline \multirow{3}{*}{$\begin{array}{l}\text { Froggatt et al, N Ireland } \\
\text { (UK), } ' 71^{18}\end{array}$} & Case-control & Social class (5) & $2.20(0.96$ to 5.11$)$ & Yes & Yes \\
\hline & & Unemployed (2) & $2.99(1.39$ to 6.53$)$ & N/A & N/A \\
\hline & & Persons/room (3) & $2.40(1.23$ to 4.72$)$ & Yes & Yes \\
\hline \multirow{2}{*}{ Kraus et al, Canada, ' $71^{19}$} & Case-control & SES (2) $\ddagger$ & $2.93(1.31$ to 6.65$)$ & N/A & N/A \\
\hline & & Maternal age (2) & 5.00 (1.64 to 16.30$)$ & N/A & N/A \\
\hline \multirow[t]{2}{*}{ Protestos et al, UK, ' $73^{20}$} & Case-control & Social class (2) & $4.79(1.37$ to 6.65$)$ & N/A & N/A \\
\hline & & Marital status (2) & 1.17 (0.48 to 2.82$)$ & N/A & N/A \\
\hline \multirow[t]{2}{*}{ Fedrick, UK, ' $74^{21}$} & Cohort & Social class (5) & 3.35 (1.62 to 7.03$)$ & Yes & Yes \\
\hline & & Maternal age (2) & $4.27(2.25$ to 8.14$)$ & N/A & N/A \\
\hline \multirow{2}{*}{$\begin{array}{l}\text { Newcastle Working Party, } \\
\text { UK, ' } 77^{22}\end{array}$} & Case-control & Unemployed (2) & 3.45 (0.71 to 18.89$)$ & N/A & N/A \\
\hline & & Maternal age (2) & $4.47(1.07$ to 20.15$)$ & N/A & N/A \\
\hline \multirow{5}{*}{$\begin{array}{l}\text { Biering-Sorensen et al, } \\
\text { Denmark, ' } 79^{23}\end{array}$} & Case-control & Marital status (2) & $4.20(2.40$ to 7.32$)$ & N/A & N/A \\
\hline & & Father's occupation (2) & 2.39 (1.47 to 4.27$)$ & N/A & N/A \\
\hline & & Economy of home (3) & 11.17 (3.4 to 39.10$)$ & Yes & Yes \\
\hline & & Persons/room (3) & 4.11 (1.50 to 11.28$)$ & Yes & Yes \\
\hline & & Housing quality (3) & 5.85 (2.99 to 11.75$)$ & Yes & Yes \\
\hline \multirow[t]{2}{*}{ Lewak et al, USA, '79 } & Cohort & Father's occupation (2) & $2.76(1.37$ to 5.66$)$ & N/A & N/A \\
\hline & & Maternal age (2) & 2.97 (1.59 to 5.53$)$ & N/A & N/A \\
\hline \multirow[t]{2}{*}{$\begin{array}{l}\text { Bartholomew and MacArthur, } \\
\text { Scotland, UK, ' } 88^{25}\end{array}$} & Case-control & Social class (not stated) & $\begin{array}{l}\text { No significant difference (no } \\
\text { figures given) }\end{array}$ & N/A & N/A \\
\hline & & Maternal age (2) & $3.67(0.88$ to 17.60$)$ & N/A & N/A \\
\hline \multirow{4}{*}{$\begin{array}{l}\text { Murphy et al, Wales, UK, } \\
\text { ' } 82^{26}\end{array}$} & Cohort & Social class (3) & $13.42(3.01$ to 83.60$)$ & Yes & Yes \\
\hline & & Unemployed (2) & $2.78(1.09$ to 6.60$)$ & Yes & Yes \\
\hline & & Maternal age (3) & 6.36 (3.00 to 13.30$)$ & Yes & Yes \\
\hline & & Area of residence (3) & $14.34(2.16$ to $>200)$ & Yes & Yes \\
\hline \multirow[t]{3}{*}{ Standfast et al, USA, ' $80^{27}$} & Cohort & Maternal age (6) & 1.98 (1.31 to 2.97$)$ & Yes & Yes \\
\hline & & Marital status (2) & 2.3 (CI not given) & N/A & N/A \\
\hline & & Maternal education (3) & 3.39 (Cl not given) & Yes & Yes \\
\hline \multirow[t]{3}{*}{ Knowleden et al, UK, ' $85^{28}$} & Case-control & Social class (5) & $3.27(1.51$ to 7.10$)$ & Yes & Yes \\
\hline & & Overcrowding (3) & $1.83(1.13$ to 2.95$)$ & Yes & Yes \\
\hline & & House repair (3) & $3.22(1.77$ to 5.86$)$ & Yes & Yes \\
\hline $\begin{array}{l}\text { Igrens and Skjaeren, } \\
' 86^{29}+\text { Oyen et al } 94^{30}+ \\
\text { Daltvi et al ' } 97^{31} \text { Norway }\end{array}$ & $\begin{array}{l}\text { Cohort(s) (1967-1981 } \\
\text { and 1967-1988, and } \\
1967-1993)\end{array}$ & Marital status (2) & $\begin{array}{l}(1967-1981): 1.89 \text { (1.59 to } \\
2.24)\end{array}$ & N/A & N/A \\
\hline & & & $\begin{array}{l}\text { (1990-1993): } 1.57 \text { (1.17 to } \\
2.10)\end{array}$ & N/A & N/A \\
\hline & & Maternal age (4) & '67-'81: 2.54 (2.04 to 3.17 ) & Yes & Yes \\
\hline & & & '90-'93: 7.03 (4.17 to 11.90$)$ & Yes & Yes \\
\hline Rintahaka and Hirvonen, & Case-control & Father's occupation (5) & 2.68 (1.34 to 5.37$)$ & Yes & Yes \\
\hline & & Marital status (2) & 2.26 (1.34 to 3.82 ) & N/A & $N / A$ \\
\hline & & Maternal age (2) & 1.75 (1.25 to 2.45$)$ & N/A & N/A \\
\hline Victora et al, Brazil, ' $87^{33}$ & Case-control & Maternal education (4) & $8.57(2.40$ to 30.80$)$ & Yes & Yes \\
\hline & & Family income (5) & $2.49(0.85$ to 7.25$)$ & Yes & Yes \\
\hline Kraus et $a^{\beta 4}+$ Hoffman & Case-control & Income (3) & $3.9(2.68$ to 5.80$)$ & Yes & Yes \\
\hline & & Maternal education (2) & 2.7 (Cl not given) & N/A & N/A \\
\hline & & Overcrowding (2) & 2.7 (Cl not given) & N/A & N/A \\
\hline & & Marital status (2) & 3.7 (Cl no given) & N/A & N/A \\
\hline & & Maternal age (2) & 2.3 (Cl not given) & N/A & N/A \\
\hline Norvenius, Sweden, ' $88^{36}$ & Cohort & Marital status (2) & $1.57(1.22$ to 2.03$)$ & N/A & N/A \\
\hline Newman, Australia, ' $88^{37}$ & Cohort & Father's occupation (2) & 1.45 (1.08 to 1.94$)$ & N/A & N/A \\
\hline & & Marital status (2) & 2.11 (1.48 to 2.99 ) & N/A & N/A \\
\hline & & Maternal age (5) & 1.76 (1.01 to 3.07$)$ & Yes & Yes \\
\hline Kraus et al, USA, ' $89^{38}$ & Case-control & Income (4) & $2.5(1.6$ to 4.0$)$ & Yes & Yes \\
\hline & & Maternal age (6) & $2.8(1.0$ to 6.7$)$ & Yes & Yes \\
\hline & & Maternal education (6) & $2.6(1.3$ to 5.3$)$ & Yes & Yes \\
\hline & & Housing density (4) & $1.6(1.0$ to 2.5$)$ & Yes & Yes \\
\hline
\end{tabular}


Table 2 Continued

\begin{tabular}{|c|c|c|c|c|c|}
\hline \multirow{2}{*}{$\begin{array}{l}\text { Author/country/year of } \\
\text { publication }\end{array}$} & \multirow[b]{2}{*}{ Study type } & \multirow{2}{*}{$\begin{array}{l}\text { Main SES measure/s } \\
\text { (number of categories) }\end{array}$} & \multirow[b]{2}{*}{ Unadjusted RR/OR $(95 \% \mathrm{Cl})^{*}$} & \multicolumn{2}{|c|}{ Gradient/trend } \\
\hline & & & & Estimated & Present \\
\hline \multirow[t]{2}{*}{ McGlashan, Australia, ' $89^{39}$} & Case-control & Unemployed (2) & 3.08 (Cl not given) & N/A & N/A \\
\hline & & Housing tenure (2) & 2.64 (Cl not given) & N/A & N/A \\
\hline \multirow[t]{2}{*}{ Kyle et al, UK, ' $90^{40}$} & Cohort & Social class (4) & $4.68(1.97$ to 11.11$)$ & Yes & Yes \\
\hline & & Maternal age (3) & 2.43 (1.54 to 3.83$)$ & Yes & Yes \\
\hline \multirow{3}{*}{$\begin{array}{l}\text { Li and Darling, USA, } \\
' 91^{41}+\text { Irwin et al ' } 92^{42}\end{array}$} & Cohort & Maternal age (5) & $3.4(2.6$ to 4.5$)$ & Yes & Yes \\
\hline & & Marital status (2) & 2.4 (2.0 to 2.8$)$ & N/A & N/A \\
\hline & & Unemployed (2) & 3.05 (2.89 to 3.21$)$ & N/A & N/A \\
\hline \multirow{3}{*}{$\begin{array}{l}\text { Mitchell et al, New Zealand, } \\
' 91^{43}+\text { Williams et al, ' } 95^{44}\end{array}$} & Case-control & Occupational class (3) & $3.70(2.66$ to 5.15$)$ & Yes & Yes \\
\hline & & Marital status (2) & 2.81 (1.84 to 4.29$)$ & N/A & N/A \\
\hline & & Maternal education (3) & $3.00(0.92$ to 9.84$)$ & Yes & Yes \\
\hline \multirow{4}{*}{$\begin{array}{l}\text { Gilbert et al, UK, ' } 92^{45} \\
\text { Haglund and Cnattingius, } \\
\text { Sweden, ' } 90^{6}+\text { Nordstrom } \\
\text { et al, ' } 93^{46}\end{array}$} & Case-control & Social class (2) & $3.3(1.6$ to 7.0$)$ & $\mathrm{N} / \mathrm{A}$ & $\mathrm{N} / \mathrm{A}$ \\
\hline & Cohort & Cohabitation (2) & 1.82 (1.07 to 3.07 ) & N/A & N/A \\
\hline & & Maternal education (5) & 2.88 (1.71 to 4.59$)$ & N/A & N/A \\
\hline & & Maternal age (4) & 4.98 (2.76 to 9.02$)$ & Yes & Yes \\
\hline \multirow{2}{*}{$\begin{array}{l}\text { Millar and Hill, Canada, } \\
{ }^{9} 93^{47}\end{array}$} & Case-control & Maternal age (5) & 4.61 (3.43 to 6.22$)$ & Yes & Yes \\
\hline & & Marital status (2) & $3.48(2.94$ to 4.11$)$ & N/A & N/A \\
\hline \multirow[t]{2}{*}{ Fujita and Kato, Japan, ' $94^{48}$} & Cohort & Marital status (2) & $5.86(2.37$ to 14.10$)$ & N/A & $\mathrm{N} / \mathrm{A}$ \\
\hline & & Maternal age (6) & $4.82(1.09$ to 20.6$)$ & Yes & Yes \\
\hline \multirow[t]{2}{*}{ Jorch et al, Germany, ' $94^{49}$} & Cohort & Maternal age (4) & $4.20(1.70$ to 10.40$)$ & Yes & Yes \\
\hline & & Maternal education (3) & $2.60(1.50$ to 4.60$)$ & Yes & Yes \\
\hline \multirow{2}{*}{$\begin{array}{l}\text { Kilkenny and Lumley, } \\
\text { Australia, ' } 94^{50}\end{array}$} & Cohort & Maternal age (2) & 6.24 (3.47 to 11.28 ) & N/A & $\mathrm{N} / \mathrm{A}$ \\
\hline & & Marital status (3) & $3.42(2.61$ to 4.48$)$ & Yes & Yes \\
\hline \multirow[t]{3}{*}{ Arntzen et al, Norway, ' $95^{51}$} & Cohort & Maternal education (3) & 1.35 (1.0 to 1.82$)$ & Yes & Yes \\
\hline & & Maternal age (3) & $2.18(1.32$ to 3.60$)$ & Yes & Yes \\
\hline & & Marital status (2) & $1.47(0.87$ to 5.90$)$ & $N / A$ & N/A \\
\hline $\begin{array}{l}\text { Klonoff-Cohen et al, USA, } \\
{ }^{9} 95^{52}\end{array}$ & Case-control & Marital status (2) & 1.97 (1.43 to 2.71$)$ & N/A & N/A \\
\hline Sanghavi, USA, ' $95^{53}$ & Cohort & Maternal age (2) & $1.73(\mathrm{Cl}$ not given) & N/A & N/A \\
\hline $\begin{array}{l}\text { Poets et al, Germany, } \\
95^{54 \star *}\end{array}$ & Case-control & Socioeconomic status (3) $+\dagger$ & 1.65 (0.85 to 3.25$)$ & Yes & $\begin{array}{l}\text { Non-significant } \\
\text { Trend }\end{array}$ \\
\hline \multirow{2}{*}{$\begin{array}{l}\text { Taylor and Sanderson, } \\
\text { USA, ' } 95^{55}\end{array}$} & Case-control & Maternal age (2) & $1.92(1.54$ to 2.38$)$ & N/A & N/A \\
\hline & & Maternal education (2) & 2.29 (1.89 to 2.79$)$ & $\mathrm{N} / \mathrm{A}$ & N/A \\
\hline $\begin{array}{l}\text { Alessandri et al, Australia } \\
\text { (Aborigines only), } 96^{56}\end{array}$ & Case-control & Maternal age (4) & $2.89(1.05$ to 8.00$)$ & Yes & Yes \\
\hline Taylor et al, USA, $96^{57}$ & Case-control & Marital status (2) & 8.02 (3.55 to 18.28 ) & N/A & N/A \\
\hline \multirow{7}{*}{$\begin{array}{l}\text { CESDI, UK, }{ }^{\prime} 96^{3}+\text { Blair } \\
\text { et al }{ }^{\prime} 96^{58}\end{array}$} & Case-control & Social class (7) & 6.95 (4.09 to 11.87$)$ & Yes & Yes \\
\hline & & Income (8) & 11.66 (3.57 to 40.6$)$ & Yes & Yes \\
\hline & & Parental education (6) & 2.47 (1.67 to 3.73$)$ & Yes & Yes \\
\hline & & Housing tenure (3) & 3.81 (2.66 to 5.50$)$ & Yes & Yes \\
\hline & & Overcrowding (4) & $31.3(10.1$ to 105.01$)$ & Yes & Yes \\
\hline & & Marital status (2) & 5.57 (2.89 to 10.83$)$ & N/A & N/A \\
\hline & & Receipt of income support (2) & 6.27 (4.15 to 9.47$)$ & N/A & N/A \\
\hline Kytir and Paky, Austria, & Cohort & Maternal education (4) & 2.27 (1.84 to 2.79$)$ & Yes & Yes \\
\hline & & Maternal age (5) & 3.01 (1.94 to 4.44 ) & Yes & Yes \\
\hline & & Marital status (2) & 1.41 (1.24 to 1.61$)$ & Yes & Yes \\
\hline Brooke et al, UK (Scotland), & Case-control & Social class (7) & 2.55 (1.66 to 3.93$)$ & Yes & Yes \\
\hline & & Deprivation index (7) & 9.59 (3.32 to 27.68$)$ & Yes & Yes \\
\hline & & Marital status (2) & $4.22(2.90$ to 6.13$)$ & N/A & N/A \\
\hline & & Maternal age (2) & 2.87 (1.85 to 4.45$)$ & $\mathrm{N} / \mathrm{A}$ & $\mathrm{N} / \mathrm{A}$ \\
\hline & & Maternal education (2) & $4.28(2.41$ to 7.62$)$ & $\mathrm{N} / \mathrm{A}$ & $\mathrm{N} / \mathrm{A}$ \\
\hline Dalviet et al, Nordic & Case-control & Marital status (2) & $2.9(1.7$ to 5.0$)$ & N/A & N/A \\
\hline & & Paternal employment (2) & $4.0(2.7$ to 5.9$)$ & N/A & N/A \\
\hline & & Maternal age (5) & $7.8(2.8$ to 21.5$)$ & Yes & Yes \\
\hline & & Maternal education (4) & $4.5(2.8$ to 7.1$)$ & Yes & Yes \\
\hline I'Hoir et al, Netherlands, & Case-control & Maternal age (2) & $1.18(1.01$ to 1.39$)$ & N/A & N/A \\
\hline & & Socioeconomic status (2) $\ddagger \ddagger$ & $1.79(1.01$ to 3.18$)$ & $\mathrm{N} / \mathrm{A}$ & N/A \\
\hline Wisborg et al, Denmark, & Cohort & Maternal age (2) & $4.39(1.83$ to 10.55$)$ & N/A & N/A \\
\hline & & Maternal education (2) & $2.23(0.73$ to 6.82$)$ & N/A & N/A \\
\hline Beal, Australia, $2000^{64}$ & Cohort & Private/public patient (2) & $2.12(1.62$ to 2.77$)$ & N/A & $\mathrm{N} / \mathrm{A}$ \\
\hline
\end{tabular}


Table 2 Continued

\begin{tabular}{|c|c|c|c|c|c|}
\hline \multirow{2}{*}{$\begin{array}{l}\text { Author/country/year of } \\
\text { publication }\end{array}$} & \multirow[b]{2}{*}{ Study type } & \multirow{2}{*}{$\begin{array}{l}\text { Main SES measure/s } \\
\text { (number of categories) }\end{array}$} & \multirow[b]{2}{*}{ Unadjusted RR/OR $(95 \% \mathrm{CI})^{*}$} & \multicolumn{2}{|c|}{ Gradient/trend } \\
\hline & & & & Estimated & Present \\
\hline \multirow{4}{*}{$\begin{array}{l}\text { Mehanni et al, Ireland, } \\
2000^{65}\end{array}$} & Cohort & Maternal age (2) & $1.78(1.48$ to 2.15$)$ & $\mathrm{N} / \mathrm{A}$ & $\mathrm{N} / \mathrm{A}$ \\
\hline & & Marital status (2) & 1.67 (1.40 to 2.15$)$ & $\mathrm{N} / \mathrm{A}$ & $\mathrm{N} / \mathrm{A}$ \\
\hline & & Father unemployed (2) & 2.15 (1.72 to 2.69$)$ & $\mathrm{N} / \mathrm{A}$ & $\mathrm{N} / \mathrm{A}$ \\
\hline & & Socioeconomic group (2)§§ & $1.26(1.18$ to 1.35$)$ & $\mathrm{N} / \mathrm{A}$ & $\mathrm{N} / \mathrm{A}$ \\
\hline $\begin{array}{l}\text { Toro and Sotonyi, Hungary, } \\
2001^{66}\end{array}$ & Case-control & Social disadvantage (2) & $6.7(1.3$ to 35.7$)$ & $\mathrm{N} / \mathrm{A}$ & $\mathrm{N} / \mathrm{A}$ \\
\hline $\begin{array}{l}\text { Arayev et al, } 17 \text { European } \\
\text { countries participating in } \\
\text { the European Concerted } \\
\text { Action on Sudden Infant } \\
\text { Death } 2001^{67}\end{array}$ & Case-control & Maternal age (3) & $9.81(5.94$ to 16.20$)$ & Yes & Yes \\
\hline Paris et al, USA, $2001^{68}$ & $\begin{array}{l}\text { Case-control***} \\
\text { (1992-1995 only) }\end{array}$ & Marital status (2) & $2.0(1.6$ to 2.5$)$ & $\mathrm{N} / \mathrm{A}$ & $\mathrm{N} / \mathrm{A}$ \\
\hline Sanderson et al, UK, $2002^{69}$ & & $\begin{array}{l}\text { Maternal age (4) } \\
\text { Residence in area of } \\
\text { poverty (2) }\end{array}$ & $\begin{array}{l}3.4(2.3 \text { to } 4.8) \\
2.33(1.06 \text { to } 5.11) \S\end{array}$ & $\begin{array}{l}\text { Yes } \\
\text { N/A }\end{array}$ & $\begin{array}{l}\text { Yes } \\
\text { N/A }\end{array}$ \\
\hline
\end{tabular}

*For studies in which SES measures have more than two categories, RR/OR refers to the risk for the most versus the least disadvantaged (reference group). ${ }^{* *}$ Additional data obtained from authors. ${ }^{* *}$ Paper includes data on study already included in paper ${ }^{39}$ and ${ }^{40}$. $\odot$ OR adjusted for pre-natal smoking. $§ O R$ adjusted for smoking and maternal depression. †Census tracts categorised on three characterisitics: educational level; crowding; housing condition. $\ddagger$ Two groups: low father unemployed or unskilled and unmarried mothers versus rest. ††Categorised into three groups (low; middle; high) based on mother's education and occupation. $\ddagger \ddagger$ Three categories (below average; average; above average) based on housing and education. §§Two categories (low; high) based on paternal occupation.

Sixteen studies reported odds ratios associated with measures of socioeconomic status after adjustment for the main socially patterned risk factors, smoking, birth weight, and sleeping position. Maternal smoking during and/or after pregnancy was adjusted for in 10 studies (table 3). In 8 of these 10 studies, the $95 \%$ confidence intervals for at least one socioeconomic status measure excluded one. One study ${ }^{51}$ did not report $95 \%$ confidence intervals but $\mathrm{p}$ values indicate that maternal education remained significant after adjustment. Birth weight was adjusted for in 11 studies and sleeping position in two studies. Socioeconomic status measures remained independently associated with sudden unexpected infant death in all but one of the studies adjusting for birth weight and in both studies adjusting for sleeping position.

\section{DISCUSSION}

Methods for the systematic review of observational studies are less well defined than for randomised control trials. Meta-analysis of observational data poses particular problems related to heterogeneity between populations and in measures used. None the less, the principles of systematic reviews, an exhaustive search for primary studies and clear, pre-defined inclusion criteria, seem to offer an approach to minimising bias in the review of observational data. In this review no attempt was made to combine data statistically but rather to examine whether a consistent relation was found between social factors and sudden unexpected infant death over time and between countries. The range of countries and populations studied, the 42 year period over which the studies were conducted, and the wide range of socioeconomic status measured used would have made combined statistics difficult to interpret and potentially misleading.

\section{Policy implications}

Preventive programmes should address the social circumstances of families with young infants in addition to promoting parental behaviour change
Fifty two studies, undertaken in 16 countries and including over 10000 sudden unexpected infant deaths during the period 1956 to 1998, were included in this systematic review. A broad definition of sudden unexpected infant death was used to take account of the changing definition of sudden unexpected death over the period studied. The results show an increased risk of sudden unexpected infant death associated with low socioeconomic status, measured by a range of indicators, which is consistent over time and between countries. These findings suggest that socioeconomic factors have an important role in the pathways leading to SUDI. Smoking is known to be strongly correlated to SIDS $^{70}$ and it has been suggested that it "accounts for" the social gradient.

The changing social pattern of women's smoking in developed countries over the 40 year period covered by these studies, the finding that in 10 studies socioeconomic status measures retained statistical significance after adjustment for maternal smoking (see table 3 ) and the variation in smoking patterns between countries ${ }^{8}$ makes it unlikely that smoking "accounts for" all the effects of socioeconomic factors in sudden infant death. ${ }^{67}$

Socioeconomic status is not a discrete variable that can be said to "cause" sudden unexpected infant death. It is likely to act, as it does in relation to mortality throughout the life course, ${ }^{71}$ as a distal determinant exerting its influence through a range of variables including low birth weight, ${ }^{72}$ smoking, ${ }^{73}$ overwrapping ${ }^{74}$ and prone sleeping ${ }^{75}$ all of which have been shown to have a social gradient in the same direction as sudden infant death. These risk factors are likely to be on the pathway from socioeconomic status to sudden infant death. As table 3 shows, socioeconomic status exerts an effect on sudden infant death independent of these major risk factors and it is possible that other socially patterned variables are mediating this independent effect.

Further work is required to elucidate the mechanisms by which socioeconomic factors influence sudden infant death. However, this study shows that the search for possible proximal causes of sudden infant death must be consistent with observed social patterns.

It has been suggested that the socioeconomic status of families with young children is "immutable"62 and 
Table 3 Studies reporting odds ratios/relative risks for socioeconomic factors adjusted for maternal smoking during or after pregnancy

\begin{tabular}{|c|c|c|}
\hline $\begin{array}{l}\text { Studies in order of year of } \\
\text { publication }\end{array}$ & Adjusted OR/RR for SES $(95 \% \mathrm{Cl})$ & Variables adjusted for \\
\hline Victora et al' $87^{33}$ & $\begin{array}{l}\text { Maternal education (per year of } \\
\text { schooling) } 0.73 \text { (0.59 to } 0.91) \\
\text { Maternal age (per year) } 0.91 \\
(0.84 \text { to } 1.00 \text { ) }\end{array}$ & $\begin{array}{l}\text { Birth weight; number of children } \\
<5 \text { years; breast feeding; smoking } \\
\text { in pregnancy }\end{array}$ \\
\hline Kyle et al ' $90^{40}$ & $\begin{array}{l}\text { Maternal age }(<20) 1.31 \\
\text { (0.77 to } 2.21) \\
\text { Social class (IV/V) } 1.50 \text { (0.84 to } 2.67) \\
\text { No employed parent } 2.34 \\
(1.41 \text { to } 3.89 \text { ) }\end{array}$ & Birth weight; ethnicity; infant sex \\
\hline Nordstrom et al ' $93^{46}$ & $\begin{array}{l}\text { Maternal education (<10 years) } \\
1.3 \text { (0.8 to } 2.2 \text { ) }\end{array}$ & $\begin{array}{l}\text { Maternal age; parity, smoking in } \\
\text { pregnancy }\end{array}$ \\
\hline Millar and Hill ' $93^{47}$ & $\begin{array}{l}\text { Maternal age }(<20) p<0.001 \\
\text { (OR not given) } \\
\text { Marital status (unmarried) } \\
p<0.001 \text { (OR not given) }\end{array}$ & $\begin{array}{l}\text { Birth weight; parity; pregnancy } \\
\text { duration; infant sex }\end{array}$ \\
\hline Fujita and Kato ' $94^{48}$ & $\begin{array}{l}\text { Marital status (unmarried) } \\
\mathrm{p}<0.001 \text { (OR not given) }\end{array}$ & $\begin{array}{l}\text { Birth weight; region; birth order; } \\
\text { infant sex }\end{array}$ \\
\hline Kilkenny and Lumley' $94^{50}$ & $\begin{array}{l}\text { Maternal age }(<20) 1.62 \\
(1.13 \text { to } 2.35) \\
\text { Marital status (unmarried) } 2.81 \\
(2.21 \text { to } 3.57 \text { ) }\end{array}$ & $\begin{array}{l}\text { Birth weight; parity; plurality; } \\
\text { gestation; mother's birthplace; } \\
\text { infant sex }\end{array}$ \\
\hline Sanghavi ' $95^{53}$ & $\begin{array}{l}\text { Maternal age }(<20) 1.73 \\
\text { (Cls not given) } \mathrm{p}<0.08\end{array}$ & $\begin{array}{l}\text { Birth weight; cigarette and alcohol } \\
\text { use in pregnancy; prenatal care; } \\
\text { race; method of delivery; gestation; } \\
\text { multiple births }\end{array}$ \\
\hline & $\begin{array}{l}\text { Maternal education (per year of } \\
\text { schooling) } 0.80 \text { (Cls not given) } p<0.01\end{array}$ & \\
\hline Alessandri et al ${ }^{\prime} 96^{56}$ & $\begin{array}{l}\text { Marital status (single) } 0.92 \\
(0.52 \text { to } 1.61 \text { ) } \\
\text { Maternal age }(<20) 2.42 \\
(0.89 \text { to } 6.56 \text { ) }\end{array}$ & $\begin{array}{l}\text { Birth weight; parity; gestation; } \\
\text { infant sex }\end{array}$ \\
\hline Blair et al'96 (CESDI study) $)^{58}$ & $\begin{array}{l}\text { Receipt of income support (UK } \\
\text { safety net benefit) } 2.81 \\
\text { (1.60 to } 4.95 \text { ) }\end{array}$ & $\begin{array}{l}\text { Smoking in pregnancy; parity; } \\
\text { marital status; income; alcohol } \\
\text { consumption in pregnancy; thermal } \\
\text { environment; maternal education; } \\
\text { bed/room sharing }\end{array}$ \\
\hline Kytir and Paky' $97^{59}$ & $\begin{array}{l}\text { Maternal education (low) } 1.45 \\
\text { (1.16 to } 1.81 \text { ) }\end{array}$ & $\begin{array}{l}\text { Birth weight; birth order; birth } \\
\text { interval }\end{array}$ \\
\hline Brooke et al ${ }^{\prime} 97^{60}$ & $\begin{array}{l}\text { Maternal age }(<27) 2.37 \\
(1.23 \text { to } 4.58)\end{array}$ & $\begin{array}{l}\text { Maternal smoking at time of death; } \\
\text { sleeping position; bed sharing; } \\
\text { social class; infant sex; gestation; } \\
\text { birth weight; breast feeding; } \\
\text { thermal environment }\end{array}$ \\
\hline & $\begin{array}{l}\text { Deprivation score (high) } 2.56 \\
(1.20 \text { to } 5.49) \\
\text { Marital status (unmarried) } 1.87 \\
\text { (1.00 to } 3.48 \text { ) }\end{array}$ & \\
\hline Daltriet et al ' $98^{61}$ & $\begin{array}{l}\text { Maternal age }(<20) 29.4(9.0 \text { to } 96.5) \\
\text { Marital status } 2.3(1.2 \text { to } 4.5) \\
\text { Paternal unemployment } 3.7(2.3 \text { to } 6.0)\end{array}$ & Smoking in pregnancy; birth order \\
\hline $\mathrm{I}^{\prime}$ Hoir et al ${ }^{\prime} 98^{62}$ & Maternal age $1.32(1.09$ to 1.60$)$ & $\begin{array}{l}\text { Smoking in pregnancy; smoking } \\
\text { after pregnancy; paternal smoking; } \\
\text { marital status; breast feeding; bed } \\
\text { sharing; birth weight; alcohol use } \\
\text { since infant's birth }\end{array}$ \\
\hline & $\begin{array}{l}\text { Socioeconomic status } 2.00 \\
\text { (1.01 to } 4.00 \text { ) }\end{array}$ & \\
\hline Toro and Sotonyi $2001^{66}$ & $\begin{array}{l}\text { Social disadvantage } 6.7 \\
\text { (1.3 to } 35.7)\end{array}$ & $\begin{array}{l}\text { Smoking in pregnancy; birth } \\
\text { weight; breast feeding; sleeping } \\
\text { position; pregnancy interval }\end{array}$ \\
\hline Paris et al $2001^{68}$ & $\begin{array}{l}\text { Marital status (unmarried) } 2.0 \\
\text { (1.6 to } 2.5 \text { ) } \\
\text { Maternal age }(<20) 3.4 \text { ( } 2.3 \text { to } 4.8 \text { ) }\end{array}$ & Smoking in pregnancy; year of birth \\
\hline Sanderson ef al $2002^{69}$ & $\begin{array}{l}\text { Residence in area of poverty } \\
2.33(1.06 \text { to } 5.11)\end{array}$ & $\begin{array}{l}\text { Maternal smoking status (not stated } \\
\text { if in pregnancy or after); maternal } \\
\text { depression; gestation }\end{array}$ \\
\hline
\end{tabular}

"unmodifiable" ${ }^{58}$ justifying exclusive concentration on proximal risk factors in the prevention of sudden infant death. However, the proportion of UK children living in poverty (by the EU definition of income below half the average after housing costs) rose from $9 \%$ in 1979 to $34 \%$ in $1995-$ $6 .^{76}$ These trends can be traced directly to government policy and could be reversed. If, as the results of this study suggest, socioeconomic factors act as distal determinants of SUDI, preventive programmes need to address the social circumstances into which infants are born as well as the health related behaviours of their parents. 


\section{Authors' affiliations}

N Spencer, School of Postgraduate Medical Education, University of Warwick, Coventry, UK

S Logan, Peninsula Medical School, University of Exeter, UK

Funding: none.

Conflicts of interest: none declared.

\section{REFERENCES}

1 Gilbert R. The changing epidemiology of SIDS. Arch Dis Child 1994;70:445-9.

2 Willinger M, James LS, Catz C. Defining the sudden infant death syndrome (SIDS): deliberations of an expert panel convened by the National Institute of Child Health and Human Development. Pediatr Pathol 1991;11:677-84.

3 Department of Health. Confidential enquiry into stillbirths and deaths in infancy (CESDI), 3rd annual report 1 January -31 December 1994. London: Department of Health, 1996.

4 Valdes-Dapena MA. Sudden and unexpected death in infancy: a review of the world literature 1954-66. Pediatrics 1967;39:123-38.

5 Valdes-Dapena MA. Sudden infant death syndrome: a review of the medical literature, 1974-1979. Pediatrics 1980;66:597-614

6 Haglund B, Cnattingius S. Cigarette smoking as a risk factor for sudden infant death syndrome: a population-based study. Am J Public Health 1990;80:29-32.

7 Mitchell EA, Ford PRK, Stewart AW, et al. Smoking and the sudden infant death syndrome. Pediatrics 1993;91:893-96.

8 Graham H. Smoking prevalence among women in the European Community 1950-1990. Soc Sci Med 1996;43:243-54.

9 Bergman AB, Ray CG, Pomeroy MA, et al. Studies of the sudden infant death syndrome in King County, Washington. III. Epidemiology. Pediatrics 1972:49:860-7.

10 Mason JK, Harkness RA, Elton RA, et al. Cot deaths in Edinburgh: infant feeding and socioeconomic factors. J Epidemiol Community Health 1980;34:35-41.

11 Anderson SC, Edelman DC, Murrell WG, et al. An epidemiological survey of SIDS in Sydney metropolitan area. J Paediatr Child Health 1993;29:445-50.

12 Kohlendorfer U, Hoberlandt E, Kiechl S, et al. Pre-and postnatal medical care and risk of sudden infant death syndrome. Acta Paediatr Scand 1997:86:600-3.

13 Cooke RWI. Smoking, intra-uterine growth retardation and sudden infant death syndrome. Int J Epidemiol 1998;27:238-41.

13a Amestad M, Anderson M, Vega A, et al. Changes in the epidemiological pattern of sudden infant death syndrome in south east Norway, 1984-1998: implications for future prevention and research. Arch Dis Child 2001;85:108-15.

14 Carpenter RG, Shaddick CW. Role of infection, suffocation and bottle-feeding in cot death: an analysis of some factors in the histories of 110 cases and their controls. Br J Prev Soc Med 1965;19:1-7.

15 Steele R, Langworth J. The relationship of antenatal and postnatal factors to sudden unexpected death in infancy. Can Med J 1966;94:1165-71.

16 Valdes-Dapena M, Birle $\mathrm{L}, \mathrm{McG}$ overn JA, et al. Sudden unexpected death in infancy: a statistical analysis of certain socioeconomic factors. J Pediatr 1968:73:387-94.

17 Strimer R, Adelson L, Oseasohn R. Epidemiologic features of 1134 sudden unexpected infant deaths. JAMA 1969;209:1493-7.

18 Froggatt $\mathbf{P}$, Lynas $M$, MacKenzie $G$. Epidemiology of sudden unexpected death in infants ('cot death') in Northern Ireland. Br J Prev Soc Med 1971;25:119-34

19 Kraus AS, Steele R, Thompson MG, et al. Further epidemiologic observations on sudden unexpected death in infancy in Ontario. Can J Public Health $1971 ; 62: 210-18$

20 Protestos CD, Carpenter RG, McWeeney PM, et al. Obstetric and perinatal histories of children who died unexpectedly ('cot death'). Arch Dis Child 1973;48:835-41.

21 Fedrick J. Sudden unexpected death in infants in the Oxford Record Linkage Area: the mother. Br J Prev Soc Med 1974:28:93-7.

22 Working Party for early childhood deaths in Newcastle. Newcastle survey of deaths in early childhood 1974/76 with special reference to sudden unexpected deaths. Arch Dis Child 1977;52:828-35.

23 Biering-Sorensell $F$, Jorgensen T, Hilden J. Sudden infant death in Copenhagen 1956-71. Acta Paediatr Scand 1979;68:1-9.

24 Lewak N, van den Berg BJ, Beckwith JB. Sudden infant death syndrome risk factors. Clin Pediatr 1979; 18:404-11.

25 Bartholomew S, MacArthur BA. Comparison of infants dying from the sudden infant death syndrome with matched live controls. Soc Sci Med 1988;27:393-7.

26 Murphy JF, Newcombe RG, Sibert JR. The epidemiology of sudden infant death syndrome. J Epidemiol Community Health 1982;36:17-21.

27 Standfast SJ, Jereb S, Aliferis D, et al. Epidemiology of SIDS in upstate NY. Am J Public Health 1980:70:1061-7.

28 Knowelden J, Keeling J, Nicholl JP. Post neonatal mortality: a multicentre study. Department of Health and Social Security. London: HMSO, 1985.

29 Igrens LM, Skjaerven R. Sudden infant death syndrome and post perinatal mortality in Norwegian birth cohorts 1967-80. Acta Paediatr Scand 1986;75:523-9

30 Oyen $\mathbf{N}$, Irgens $L M$, Skjaerven $R$, et al. Secular trends of sudden infant death syndrome in Norway 1967-1988: application of a method of case identification to Norwegian registry data. Paediatr Perinat Epidemiol 1994:8:263-81.
31 Daltviet AK, Oyen N, Skiaerven R, et al. The epidemic of SIDS in Norway 1967-93: changing effects of risk factors. Arch Dis Child 1997;77:23-7.

32 Rintahaka PI, Hirvonen J. The epidemiology of sudden infant death syndrome in Finland in 1969-1980. Forensic Sci Int 1986;30:219-33.

33 Victora CG, Nobre LC, Lombardi C, et al. Quadro epidemiologico das mortes subitas na infancia em cidades gauchas (Brasil). [In Portugese]. Rev Saude Publica 1987; 21:490-6.

34 Kraus JF, Peterson DP, Standfast SJ, et al. The relationship of socio-economic status and sudden infant death syndrome: confounding or effect modification? In: Harper RM, Hoffman HJ, eds. Sudden infant death syndrome: risk factors and basic mechanisms. New York: PMA Publishing, 1988.

35 Hoffman HJ, Damus K, Hillman L, et al. Risk factors for SIDS: results of the National Institute of Child Health and Human Development SIDS cooperative epidemiological study. In: Harper RM, Hoffman HJ, eds. Sudden infant death syndrome: risk factors and basic mechanisms. New York: PMA Publishing, 1988

36 Norvenius SG. The contribution of SIDS to infant mortality trends in Sweden. In: Harper RM, Hoffman $\mathrm{HJ}$, eds. Sudden infant death syndrome: risk factors and basic mechanisms. New York: PMA Publishing, 1988.

37 Newman NM. The epidemiology of sudden iruant death syndrome in Australia with particular reference to Tasmania, 1975-81. In: Harper RM, Hoffman $\mathrm{HJ}$, eds. Sudden infant death syndrome: risk factors and basic mechanisms. New York: PMA Publishing, 1988.

38 Kraus JF, Greenland S, Bulterys M. Risk factors for sudden infant death syndrome in the US Collaborative Perinatal Project. Intl J Epidemiol 1989:18:113-20.

39 McGlashan N. Sudden infant deaths in Tasmania, 1980-1986: a seven year prospective study. Soc Sci Med 1989;29:1015-26.

40 Kyle D, Sunderland R, Stonehouse M, et al. Ethnic differences in incidence of sudden infant death syndrome in Birmingham. Arch Dis Child 1990:65:830-3

41 De-Kun Li, Daling JR. Maternal smoking, low birth weight and ethnicity in relation to sudden infant death syndrome. Am J Epidemiol 1991; 134:958-64.

42 Irwin KL, Mannino S, Daling JR. Sudden infant death syndrome in Washington State: why are native American infants at greater risk than white infants? J Pediatr 1992;121:242-7.

43 Mitchell EA, Scragg R, Stewart AW, et al. Results from the first year of the New Zealand cot death study. N Z Med J 1991;104:71-6.

44 Williams SM, Taylor BJ, Mitchell EA, et al. Sudden infant death syndrome in New Zealand: are risk scores useful? J Epidemiol Community Health 1995;49:94-101.

45 Gilbert R, Rudd P, Berry PJ, et al. Combined effect of infection and heavy wrapping on the risk of sudden unexpected infant death. Arch Dis Child 1992;67:171-7

46 Nordstrom M-L, Cnattingius S, Haglund B. Social differences in Swedish Infant Mortality by cause of death, 1983 to 1986. Am J Public Health 1993;83:26-30

47 Millar WJ, Hill GB. Prevalence of and risk factors for sudden infant death syndrome in Canada. Can Med Assoc J 1993; 149:629-35.

48 Fujita T, Kato N. Risk factors for SIDS in Japan: a record-linkage study based on vital statistics. Acta Paediatr Jpn 1994;36:325-8.

49 Jorch G, Schmidt-Troschke S, Bajanowski T, et al. Risk factors for sudden infant death (SID): epidemiologic study in two German districts 1990-1992. [In German]. Monatsschr Kinderheilkd 1994;142:45-51.

50 Kilkenny M, Lumley J. Ethnic differences in the incidence of the sudden infan death syndrome (SIDS) in Victoria, Australia 1985-1989. Paediatr Perinat Epidemiol 1994;8:27-40

51 Arntzen A, Moum T, Magnus P, et al. Is the higher postneonatal mortality in lower social status groups due to SIDS? Acta Paediatr Scand 1995;84:188-92.

52 Klonoff-Cohen H, Edelstein SL. Bed sharing and the sudden infant death syndrome. BMJ 1995;311:1269-71

53 Sanghavi DM. Epidemiology of sudden infant death syndrome (SIDS) for Kentucky infants. J Ky Med Assoc 1995;93:286-90.

54 Poets CF, Schlaud M, Kleeman WJ, et al. Sudden infant death and materna cigarette smoking: results from the Lower Saxony Perinatal Working Group. Eur J Paediatr 1995; 154:326-9.

55 Taylor JA, Sanderson M. A re-examination of the risk factors for the sudden infant death syndrome. J Pediatr 1995;126:887-91.

56 Alessandri LM, Read AW, Burton FJ, et al. An analysis of sudden infant death syndrome in Áboriginal infants. Early Hum Dev 1996;45:235-44.

57 Taylor JA, Krieger JW, Reay DT, et al. Prone sleep position and sudden infant death syndrome in King County, Washington: a case:control study. J Pediatr 1996:128:626-30.

58 Blair PS, Fleming PJ, Bacon C, et al. Smoking and the sudden infant death syndrome: results from 1993-5 case-control study for confidential inquiry into stillbirths and death in infancy. BMJ 1996;313:195-9.

59 Kytir J, Paky F. Sudden infant death syndrome in Austria. Monatsschr Kinderheilkd 1997; 145:613-18.

60 Brooke H, Gibson A, Tappin D, et al. Case-control study of sudden infant death syndrome in Scotland. 1992-5. BMJ 1997:314:1516-20.

61 Dalviet AK, Irgens LM, Oyen N, et al. Sociodemographic risk factors for sudden infant death syndrome: associations with other risk factors. Acto Paediatr Scand 1998;87:284-90.

62 I'Hoir MP, Engelberts AC, van Well G, et al. Case-control study of current validity of previously described risk factors for SIDS in the Netherlands. Arch Dis Child 1998:79:386-94.

63 Wisborg K, Kesmodel U, Henriksen TB, et al. A prospective study of smoking during pregnancy and SIDS. Arch Dis Child 2000;83:203-6.

64 Beal SM. Sudden infant death syndrome in South Australia 1968-97. Part 1 : changes over time. J Paediatr Child Health 2000;36:540-7. 
65 Mehanni M, Cullen A, Kiberd B, et al. The current epidemiology of SIDS in Ireland. Irish Med J 2000;93:264-7.

66 Toro K, Sotonyi P. Distribution of prenatal and postnatal risk factors for sudden infant death in Budapest. Scand J Prim Health Care 2001 19:178-80.

67 Aryayev N, Kukushkin V, Nepomyashcha V. The significance of ante- and perinatal periods for formation of risk of sudden infant death syndrome. Gin Pol 2001;72:931-9.

68 Paris CA, Remler R, Daling JR. Risk factors for sudden infant death syndrome: changes associated with sleep position recommendations. J Pediatr 2001;139:771-7.

69 Sanderson CA, Cowden B, Hall DMB, et al. Is postnatal depression a risk factor for sudden infant death? Br J Gen Practice 2002;52:636-40.

70 Golding J. Sudden infant death syndrome and parental smoking - a literature review. Paediatr Perinat Epidemiol 1997;1 1:67-77.
71 Davey Smith G, Blane D, Bartley M. Explanations of socio-economic differences in mortality: evidence from Britain and elsewhere. Eur J Public Health 1994;4:131-44

72 Reading R, Openshaw S, Jarvis SN. Measuring child health inequalities using aggregations of enumeration districts. J Public Health Med 1990;12:160-7.

73 Graham H. Smoking among working class mothers. Primary Health Care 1993;3:15-16.

74 Ponsonby AL, Dwyer T, Gibbons LE, et al. Thermal environment and sudden infant death syndrome: case-control study. BMJ 1992;304:277-82.

75 Ponsonby AL, Dwyer T, Kasl SV, et al. An assessment of the impact of public health activities to reduce the prevalence of the prone sleeping position during infancy. The Tasmanian cohort study. Prev Med 1994;23:402-8.

76 Department of Social Security. Households below average income 19791996-7. London: The Stationery Office, 1998.

\section{Speaker's corner}

\section{Outsourcing: wagering protection}

O utsourcing is a growing trend, relieving business pressure to flex with the erratic work demands of a dynamic market. Practically speaking, when a process is fairly consistent across an industry, outsourcing seems to make sense, as long as one can sufficiently detail the work specifications. To be successfully outsourced, a project must be translated into logical steps, those steps communicated, and executed-it must be well managed.

Not surprising, the emigration of project management to low wage economies has economic motivation. For all the resistance against such business practice, the long term effect of outsourcing on community health is not obvious. While offering flexibility and diversity to workers and employers, its trade off is stability and many times, expertise. Still, outsourcing offers an opportunity to globalise worker standards.

Against this backdrop, the stage is set for the Forum Barcelona (http://www.barcelona2004.org). The world Forum is organised around three core themes: (1) cultural diversity, (2) sustainable development, and (3) conditions for peace. In fact, conversation has already begun via the web and preforum dialogues.

\section{CULTURAL DIVERSITY}

That commerce fosters cultural diversity is undeniable. Outsourcing to the majority of the world brings India and the UK in contact, Brazil and Japan, China and the USA. Within a country, we can see an intersection of cultures. Also undeniable is the conflict concomitant with diversity. It is difficult to understand another who does not speak your language; even for people who speak the same language, a word can connote vastly different meanings. It takes time to develop understanding and trust. We promote effective dialogue by accentuating the beneficial aspects of diversity while acknowledging the inherent conflict in disparity.

\section{SUSTAINABLE DEVELOPMENT}

The business practice of contracting workers from low wage economies like the Far East and eastern Europe also frames the question of what kind of growth is sustainable, and how do we sustain healthy communities. The global workforce cries for global standards for health and safety. Whether jobs are local or shipped to far away shores, all workers deserve protection. Smart regulations surely do not hinder profitability-amidst the toughest regulation in industry, we see some of the most profitable companies. The conundrum of economic prosperity as a requisite for community health is based, in part, on the riddle of productivity. Can industry increase productivity with greater return on investment, and concurrently preserve worker security?

\section{CONDITIONS FOR PEACE}

Clearly, the social contract between employers and workers is under revision. Those with the advantage of wealth, power, or prestige may craft policies toward or away from greater social justice. One measure of success will be the degree to which we reconcile the well established links of health with a decent family income, adequate housing, early childhood development, and a good education.

\section{HOW TO CREATE A HEALTHY WORKPLACE}

Ours is not a unique situation. Social reformers have helped close sweatshops, end child labour, and give workers a fair wage for a days' work in Western Europe, Scandinavia, and the USA. Today, with many workers in safe jobs, in comfortable offices, with reasonable pay, we are called to extend reform of unsafe working conditions globally. As health professionals, we can take a page from the theory of change management ${ }^{1}$ :

- Establish a sense of urgency-why is this change needed now?

- Gather a coalition to develop a strategy_for direction and support

- Communicate the strategy-where do we want to go?

- Empower others to act-those closest to the fire must stoke it

- Generate short term wins-celebrate successes publicly

- Produce greater change.

While thoughtful discussion is valuable, more important is implementing effective solutions. Companies can harmonise existing health and safety standards or stipulate such practice when outsourcing to escape liability and so all are protected, especially those with low wages. To paraphrase one executive, we have the capacity to do more good, for more people, than any other generation on the planet. The question is: How do we respond?

D F Salerno Clinical Communications Scientist, Pfizer Global Research and
Development-Michigan Laboratories, 2800 Plymouth Road, Ann Arbor, MI, USA; deborah.salerno@pfizer.com

\section{REFERENCE}

1 Kotter JP. Leading change. Boston, MA: Harvard Business School Press, 1996. 